\title{
DOES FULLY RADIOACTIVE GLASS BEHAVE DIFFERENTLY THAN SIMULATED WASTE GLASS?
}

\author{
X. Feng, J. K. Bates, C. R. Bradley, and E. C. Buck \\ Argonne National Laboratory, 9700 South Cass Avenue, Argonne, IL 60439 \\ ANL/CMT/CP--76241 \\ DE93 005574
The submitted manuscript has been authored
by a contractor of the U.S. Government
Accordingly, the U.S. Government retoins
nonexclusive, royalty-free license to publish
or reproduce the published form of this
contuibution, or allow others to to so, for
U.S. Government purposes. \\ under contrict No. W.31.109ENG.38. \\ Submitted to \\ 1992 Fall Materials Research Society Meeting \\ Scientific Basis for Nuclear Waste Management Symposium \\ Boston, Massachusetts \\ November 30-December 4, 1992
}

Work supported by the U.S. Department of Energy, Office of Environmental Restoration and Waste Management, under Contract W-31-109-ENG-38.

\section{Mitsitn}




\title{
DOES FULLY RADIOACTIVE GLASS BEHAVE DIFFERENTLY THAN SIMULATED WASTE GLASS?
}

\author{
X. Feng, J. K. Bates, C. R. Bradley, and E. C. Buck \\ Argonne National Laboratory, 9700 South Cass Avenue, Argonne, IL 60439
}

\section{ABSTRACT}

Static lests at SAV (ratio of surface area of glass to solution volume) $20,000 \mathrm{~m}^{-1}$ on SRL 200 glass compositions show that, at long test periods, the simulated nuclear waste glass (nonradioactive) leaches faster than the cor: sponding radioactive glass by a factor of about 40, although comparative tests, done through 560 days, at lower SAV, $2000 \mathrm{~m}^{-1}$, indicate little differenct in the leach behavior of the two types of glasses. The similarity in leach behavior between radioactive and simulated glasses at SAV of $2000 \mathrm{~m}^{-1}$ or lower is also observed for SRL 165/42 and 131/11 compositions. The accelerated glass reaction with the simulated glass $200 \mathrm{~S}$ is associated with the formation of crystalline phases such as clinoptilolite (or potassium feldspar), and a pH excursion. The radiation field generated by the fully radioactive glass reduces the solution $\mathrm{pH}$. This lower $\mathrm{pH}$, in turn, may retard the onset of increased reaction rate. The radiation field generated by the radioactive glasses does not directly affect the stability of the glass surface alteration layer under those conditions where the radioactive and simulated glasses react at the same rate. These results suggest that the fully radioactive nuclear waste glass $200 \mathrm{R}$ may maintain a much lower leach rate than the simulated 200S, if the lower $\mathrm{pH}$ in the $200 \mathrm{R}$ leachate can be sustained. Meaningful comparison tests between radioactive and simulated nuclear waste glasses should include long-term and high SAV tests.

\section{INTRODUCTION}

There has been interest in the comparison of the leach behavior between fully radioactive and simulated nuclear waste glasses [1-6], to assess the differences in reaction mechanism, type, and sequence of secondary phases, and the relative durability among the two types of glasses. The results from these comparisons will provide confidence in the use of the large amount of data generated in the studies of simulated nuclear waste glass for the modeling of performance of radioactive glasses. Most of the previous comparison studies $[1,2,4]$ have been performed at a low to intermediate ratio of glass surface area to solution volume (SAV $\leq 1100 \mathrm{~m}^{-1}$ ) and for time periods of less than one year. These studies have generally concluded there is little difference in leach behavior between the two glass types. The study reported here reinvestigates that conclusion by utili ing an extensive test matrix, with SAN ranging between 340 to $20,000 \mathrm{~m}^{-1}$ on three waste glass compositions, for time periods planned up to eight years. The early results reported from this study $[3,6]$ are consistent with other studies $[1,2,4]$, in that the leach beahvior of simulated waste glasses is similar to that of fully radioactive glasses. However, the longer-term tests at higher SAV suggest that the leach beahvior of the two types of glass diverges, under certain conditions. In this paper, the longer-term comparison of the leach behavior is discussed.

\section{EXPERIMENTAL}

The experimental details have been reported previously [3]. Briefly, three groups of glass compositions, designated 165/42, 131/11, and 200 irave been used. The fully radioactive waste glass compositions ( $R$ glasses) were made in the $S R L$ in-cell minimelter, 
using corresponding glass frits plus sludge from various high-level waste tanks at Westinghouse Savannah River Site. The simulated glass compositions (S glasses) were made to have the same compositions as the R glasses, but with no actinides. The glasses were tested at $90^{\circ} \mathrm{C}$ in EJ-13 water (repository groundwater equilibrated with luff rock) at SAV $=340 \mathrm{~m}^{-1}$ (monolith), $2000 \mathrm{~m}^{-1}$ (powder), and 20,000 $\mathrm{m}^{-1}$ (with glass 200 powders only). These tests have been in progress up to 30 months and most of the tests were done in duplicate. The test veseol is a $22 \mathrm{~mL} 304 \mathrm{~L}$ stainless steel vessel with a copper gasket. The solution analyses include leachate $\mathrm{pH}$ (at room temperature), cations, selected anions, and actiricjes. Analyses were done on solutions filtered through 0.45 and $0.005 \mu \mathrm{m}$ filters, and the errors associated with solution analyses are estimated to be less than $10 \%$. The leached glass surfaces were examined optically and with SEM/EDS (scanning electron microscopy/energy dispersive spectroscopy), TEM (Iransmission electron microscopy), and SIMS (recondary ion mass spectroscopy).

\section{RESULTS}

The comparison of the normalized release (based on $0.45 \mu \mathrm{m}$ filtrates) of $\mathrm{B}, \mathrm{Li}, \mathrm{Na}$, and $\mathrm{Si}$ for all the glass compositions tested at $2000 \mathrm{~m}^{-1}$ is shown in Figure 1. For $165 / 42$ compositions at timus up to 560 days, the normalized $\mathrm{Li}$ and $\mathrm{Si}$ relcases are similar for both $\mathrm{R}$ and $\mathrm{S}$ glasses. The $\mathrm{B}$ and $\mathrm{Na}$ releases from $165 / 42 \mathrm{R}$ are higher than those from $165 / 42 S$, but by less than $150 \%$ (Figures $1 \mathrm{a}$ and $1 \mathrm{~b}$ ). For $131 / 11$ compositions at times up to 280 days, the $\mathrm{B}, \mathrm{Li}, \mathrm{Na}$, and $\mathrm{Si}$ releases from 131/11S are higher than those from $131 / 11 \mathrm{R}$, with differences being less than 300\% (Figures $1 \mathrm{C}$ and $1 \mathrm{~d}$ ). For 200 compositions at times up to 280 days, the B, Li, Na, and Si releases from 200 S are generally higher than those from 200R (Figures 1e and $1 f$ ). The trends of the solution results from testing each of these glasses at $340 \mathrm{~m}^{-1}$ (not shown here) are similar to these results at $2000 \mathrm{~m}^{-1}$. While the differences that are measured for the reactivity of the $R$ and $S$ glasses are analytically significant, the absolute differences are relatively small and the trends in the data suggest for each glass type ( $R$ and $S$ ) the same reaction processes are rate-controlling.

However, the leach behavior of the 200-based composition at $20,000 \mathrm{~m}^{-1}$ indicates that there may be a large difference in the long-term reactivity between $R$ and $S$ glasses. Figure 2 shows that the glass dissolution reaction for $200 \mathrm{~S}$ glass at $20,000 \mathrm{~m}^{-1}$ is greatly accelerated between 182 and 364 days. The increased reaction rate was verificd by two additionil tests terminated at 300 and 390 days. The normalized release in torms of $B$, $\mathrm{Na}, \mathrm{Li}$, and $\mathrm{Si}$ increased by a factur of $35,23,9$, and 10, respectively, from 182 to 364 days. The solution $\mathrm{pH}$ increases from 11.82 to 12.29 (Figure 2). The 100-200 mesh glass powder of 2005 transforms into a cakc-like material that adheres to the walls of the test vessel and a large quantity of white crusty precipitated material forms on top of and between the glass powder (Figure $3 \mathrm{C}$ ). Examination of the reacted surface layers on the glass samples by both SEM and AEM (analytical electron microscopy) reveals rapid thickening of the surface layers, with abundant crystalline phase formation, as shown in Figure 3. The anion concentrations of phosphate, suifate, chloride, and fluoride also increases up to 70 times, as the rate increases, although the original content of these anions in the bulk glass are low (which suggests a preferential release of these anions from glass).

On the other hand, the release rate for $200 \mathrm{R}$ at $20,000 \mathrm{~m}^{-1}$ shows almost no increase at all during the same interval, and the slow release trend extends through 560 days (Figure 2). The leachate $\mathrm{pH}$ of the 560 -day lest of $200 \mathrm{R}$ is still 11.64 , similar to the $\mathrm{pH}$ at 15 days. The various anion concentrations of $200 \mathrm{R}$ are nearly constant throughout of the 560-day period. At 364 days, the leach rate of $200 \mathrm{~S}$ is $39,31,16$, and 9 times higher than $200 \mathrm{R}$ in terms of $\mathrm{B}, \mathrm{Na}, \mathrm{Si}$, and $\mathrm{Li}$ release, respectively. The $\mathrm{pH}$ of $200 \mathrm{~S}$ is 0.6 unit higher than the corresponding $\mathrm{pH}$ of 200R, at 364 days. 

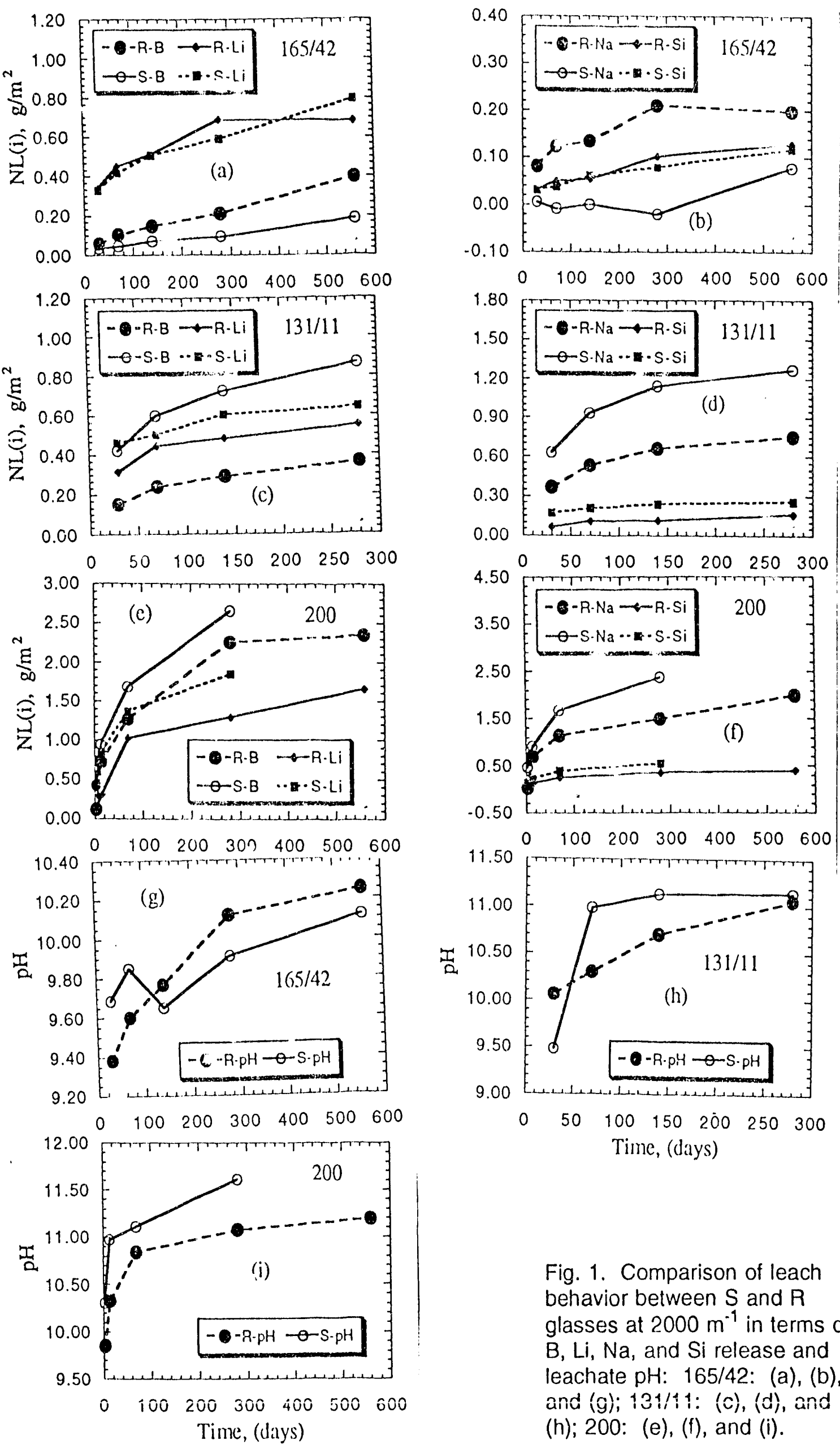

Fig. 1. Comparison of leach behavior between $S$ and $R$ glasses at $2000 \mathrm{~m}^{-1}$ in terms of $\mathrm{B}, \mathrm{Li}, \mathrm{Na}$, and $\mathrm{Si}$ release and leachate $\mathrm{pH}$ : 165/42: (a), (b), and $(g) ; 131 / 11:(c),(d)$, and (h); 200: (e), (f), and (i). 

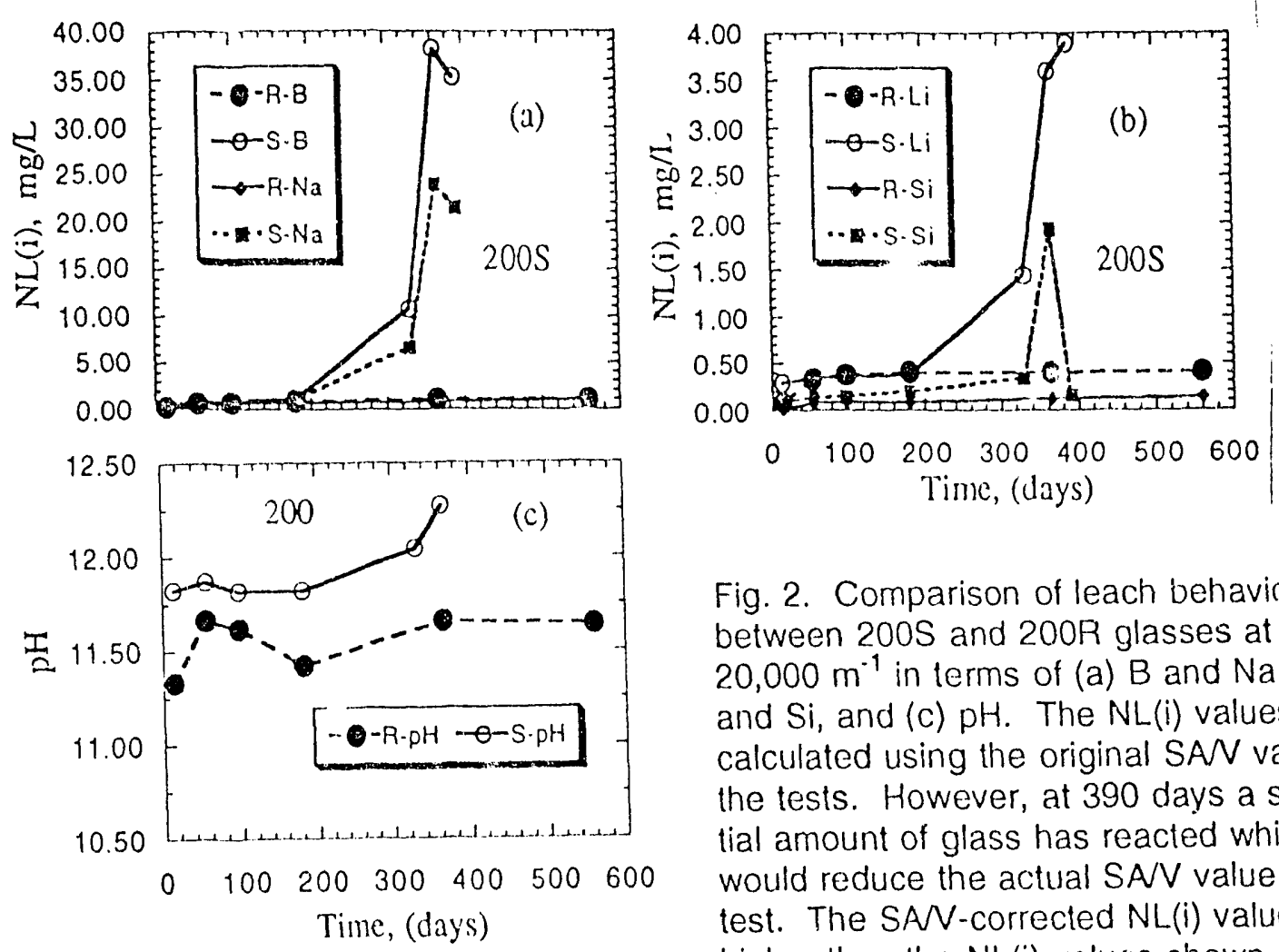

Fig. 2. Comparison of leach behavior between $200 \mathrm{~S}$ and $200 \mathrm{R}$ glasses at $20,000 \mathrm{~m}^{-1}$ in terms of (a) B and $\mathrm{Na}$, (b) $\mathrm{Li}$ and $\mathrm{Si}$, and $(\mathrm{c}) \mathrm{pH}$. The $\mathrm{NL}(\mathrm{i})$ values are calculated using the original SAN value of the tests. However, at 390 days a substantial amount of glass has reacted which would reduce the actual SAV value of the test. The SAV-corrected NL(i) values are higher than the $\mathrm{NL}(i)$ values shown above.

The uranium concentration in the leachate, of 2005 at $20,000 \mathrm{~m}^{-1}$, also increases by a factor of 13 , after the acceleration. This is somewhat surprising, due to the basic $\mathrm{pH}$ of the leachates, which would suggest a luw solubility for uranium. It is possible that the increased $U$ in solution was a result of the higher concentration of anions in the rateaccelerated glass leachate. During acceleration, the concentration increases are 22 times for $F^{-}$( 7 to $147 \mathrm{mg} / \mathrm{L}$ ), 21 times for $\mathrm{Cl}^{-}$(9 $10187 \mathrm{mg} / \mathrm{L}$ ), 13 times for $\mathrm{HPO}_{4}^{-2}$ (77 to $950 \mathrm{mg} / \mathrm{L})$, and 70 times for $\mathrm{SO}_{4}^{-2}(165$ to $11550 \mathrm{mg} / \mathrm{L})$. The retention of actinides or rare earth elements by waste glasses has been found to decrease dramatically, when the glasses are tested in brine solutions or other solutions, where anion concentrations are high $[7,8]$.

The surface layers are also significantly different before and after acceleration. The surface layer of 2005 at $20,000 \mathrm{~m}^{-1}$ before acceleration is a single-layer structure as shown in Figures $3 \mathrm{~d}$ and $3 \mathrm{e}$. The layer thickness grows slowly with time, being about $150 \mathrm{~nm}$ thick (Figure $3 \mathrm{~d}$ ) at 38 days, and about $300 \mathrm{~nm}$ (Figure 3e) at 182 days. After acceleration, the surface layers increase to about $6500 \mathrm{~nm}$ in thickness with two distinct regions (Figure $3 \mathrm{f}$ ). The crystalline region has a thickness of about $2000 \mathrm{~nm}$. There is a large amorphous alteration region (more than $4500 \mathrm{~nm}$ in thickness) below the crystalline region as shown in Figure 3f. Several types of phases have been identified in the crystalline region. A dominant phase is the elongated prism-shaped crystals with a composition if $\mathrm{Si}, 61.5 ; \mathrm{Al}, 22.8 ; \mathrm{K}, 9.0 ; \mathrm{Ca}, 4.0$ element wt\%. The composition shows significant ve:iations in the amounts of $\mathrm{K}$ and $\mathrm{Ca}$, depending on the location of the phase in the surface ayer being examined. The electron diffraction pattern of the phase matches well with the crystal spacing of a clinoptilolite [9]. The ideal formula for this zeolite phase is $\left(\mathrm{Na}_{2}, \mathrm{~K}_{2}\right) \mathrm{O} \cdot \mathrm{Al}_{2} \mathrm{O}_{3} \cdot 10 \mathrm{SiO}_{2} \cdot 8 \mathrm{H}_{2} \mathrm{O}(\mathrm{Ca}$ and $\mathrm{Mg}$ also present; $\mathrm{Na}, \mathrm{K}>>\mathrm{Ca})$ [9]. However, the composition, d-spacings, and the morptiology of this phase are also consistent with a $\mathrm{K}$-feldspar phase. Formation of K-feldspar from zeolite has been well documented [9], but since the phase obseryed is extremely sensitive to electron irradiation, an indication of containing water, it is more likely the phase is clinoptilolite. The other phases are a 
(a)

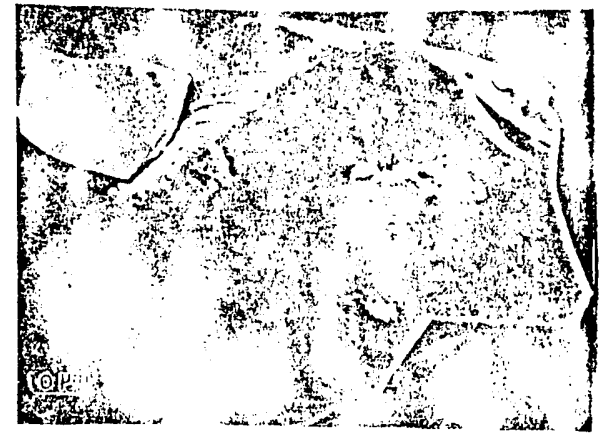

(b)

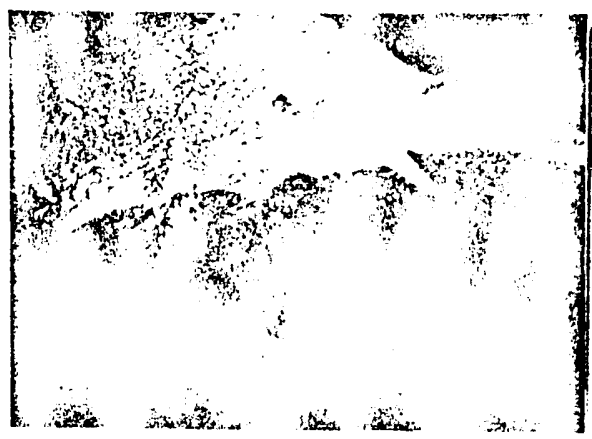

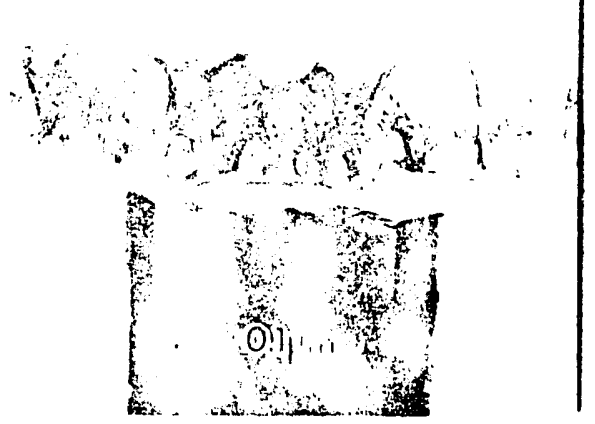

(d)

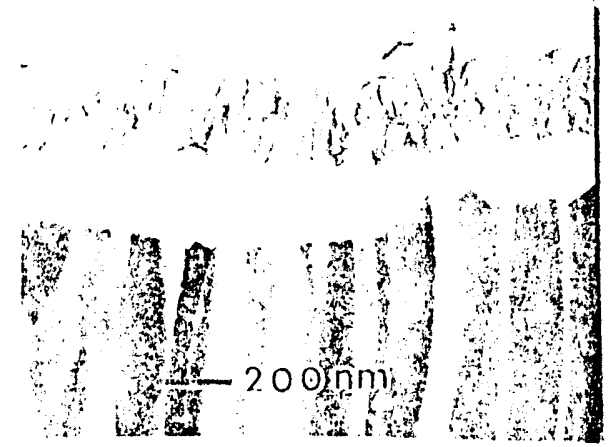

(e)

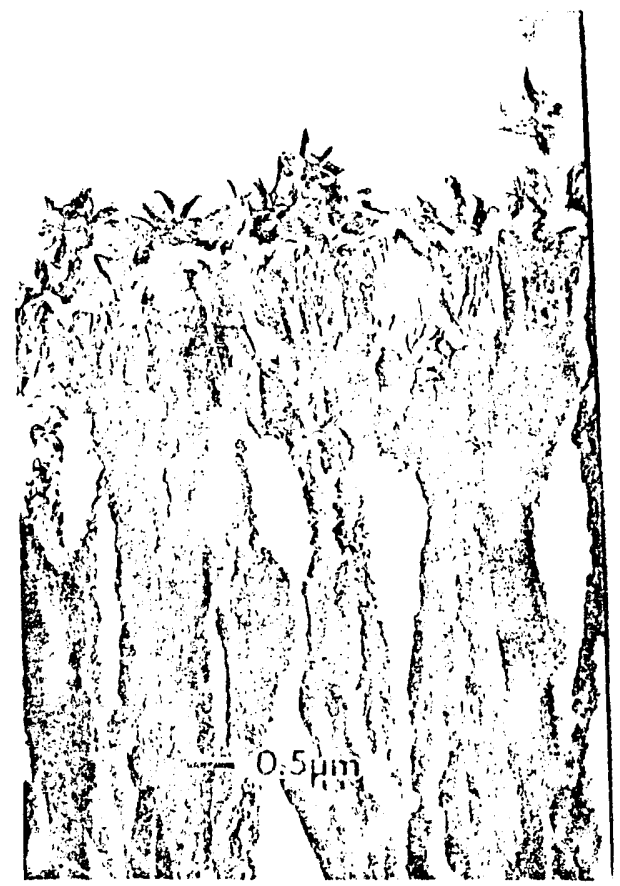

(g)
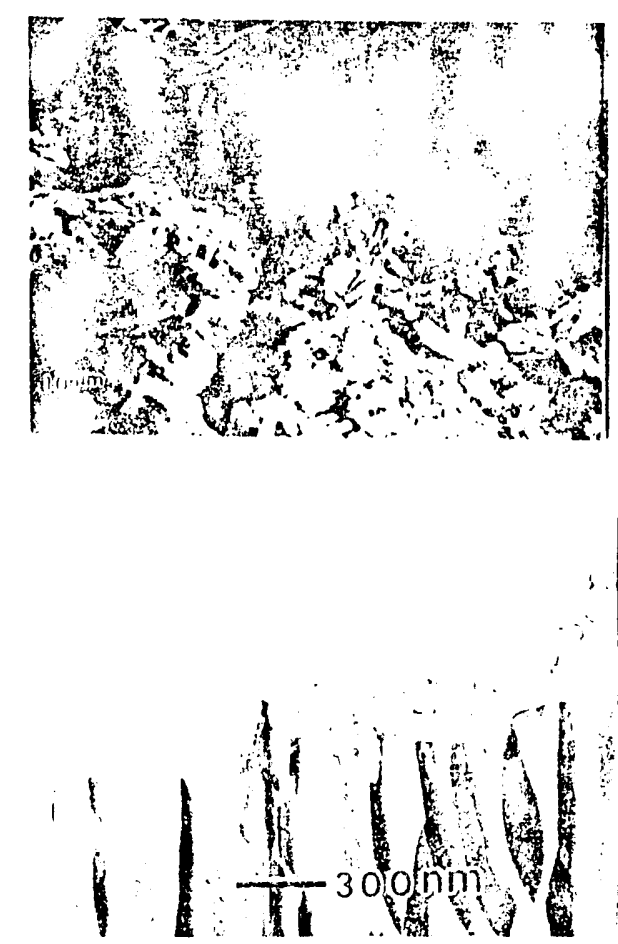

Fig. 3. Surface layer examination on reacted 200 glass compositions at $20,000 \mathrm{~m}^{-1}$ : SEM micrographs of the top surface views on $200 \mathrm{~S}$ samples reacted for (a) 98 days, (b) 182 days, and (c) 364 days; TEM micrographs of cross-sections on samples reacted for (d) 98 days of 200S, (e) 182 days of 200S, (f) 364 days of 200S, and (g) 364 days of $200 \mathrm{R}$. 
Fe-rich clay as shown in Figures $3 d-3 g$, an almost pure amorphous Si phase that is both isolated from and in close vicinity with the clay phase, and a Si-Ca phase which is a button-like mass.

Figure $3 \mathrm{~g}$ is a TEM micrograph of $200 \mathrm{R}$ glass reacted for 364 days. The surface layer thickness is $150-300 \mathrm{~nm}$, which is similar to that of $200 \mathrm{~S}$ at 182 days. The compositions of the surface layer in the 364 -day sample of $200 \mathrm{R}$ are also similar to the layer composition of 2005 before acceleration.

\section{DISCUSSION}

The results, on tests done at 340 and $2000 \mathrm{~m}^{-1}$, show only small differences in leach behavior between radioactive and simulated glasses of $165 / 42,131 / 11$, and 200 compositions for time periods up to 560 days. On the other hand, the tests at SAV of $20,000 \mathrm{~m}^{-1}$ show up to a factor of 40 difference in leach rates between $200 \mathrm{R}$ and $200 \mathrm{~S}$ glasses within 364 days.

To explain the observed leach behavior, the correlation between solution $\mathrm{pH}$ and the extent of reaction is instructive. For the 200-based glasses, the solution $\mathrm{pH}$ values for all of the 340 and $2000 \mathrm{~m}^{-1}$ tests to date and $20,000 \mathrm{~m}^{-1}$ tests prior to 330 days are lower for the $\mathrm{R}$ glass compared to the $\mathrm{S}$ glass. This $\mathrm{pH}$ lowering is attributed to the radiation effect which generates various acids in the system [6]. For the 200 and 131/11-based compositions, the reaction is dominated by network hydrolysis. This process is favored by higher solution $\mathrm{pH}$ values, and thus when the radiation effect lowers the leachate $\mathrm{pH}$, the $R$ glasses initially react more slowly than the $S$ glasses (Figures $1 \mathrm{~h}$ and $1 \mathrm{i}$ ). On the inther hand, the do ninant reaction process for the $165 / 42$ compositions during the time periods examined is ion-exchange. The initial lower $\mathrm{pH}$ for $165 / 42 \mathrm{R}$ compared to $165 / 42 \mathrm{~S}$ (Figure 1, favors the ion-exchange reaction more in the $\mathrm{R}$ glass than in $S$ glass. As the ion-exchange reaction continues, the solution $\mathrm{pH}$ increases, which in turn begins to promote the network hydrolysis reaction. This explains why 165/42R is slightly more reactive than 165/42S (Figures $1 \mathrm{a}$ and $\mathrm{Hb}$ ) in terms of $\mathrm{B}$ and $\mathrm{Na}$.

The accelerated reaction of $200 \mathrm{~S}$ after 330 days can also be correlated with solution $\mathrm{pH}$. Solution $\mathrm{pH}$ is known to be one of the dominant effects on nuclear waste glass reaction $[10,11]$. Initially at $20,000 \mathrm{~m}^{-1}$, the $200 \mathrm{~S}$ glass leachates have $\mathrm{pH}$ values of $11.82 \pm 0.05$ during $15,56,98$, and 182 days, while the $200 \mathrm{R}$ have $\mathrm{pH}$ values of $11.65 \pm 0.13$ between the 15 and 560 days. Additionally, the leach rates of both $200 \mathrm{~S}$ (before acceleration) and 200R (up to 560 days) decrease with time, and the leach rate for $200 \mathrm{R}$ at $20,000 \mathrm{~m}^{-1}$ is always lower than corresponding $200 \mathrm{~S}$. However, after 330 days the $\mathrm{pH}$ of the $200 \mathrm{~S}$ glass exceeds 12.0 and the reaction rate of $200 \mathrm{~S}$ greatly increases, while the $\mathrm{pH}$ of $200 \mathrm{R}$ leachate at 560 days is still similar to its $\mathrm{pH}$ at the beginning of the test (Figure 2c) and shows no sign of $\mathrm{pH}$ excursion. This lower $\mathrm{pH}$ for $200 \mathrm{R}$ may retard the onset of increased glass reaction rate. It is possible that no reaction acceleration for $200 \mathrm{R}$ will occur if the radiation effect of $200 \mathrm{R}$ can maintain the leachate $\mathrm{pH}$ below 11.8. The similarity, in the thickness, composition, and morphology of the surface alteration layers between the 182-day sample of 200S (Figure 3e) and the 364-day sample of 200R (Figure $3 \mathrm{~g}$ ), suggests that the radiation field of radioactive glass has not produced any direct effect on the development of surface alteration layers.

Another possible explanation for the observed rate acceleration is the formation of a suite of crystalline phases in 2005 samples but not in $200 \mathrm{R}$ samples. As the glass reaction progresses, the solution concentration increases. The increased solution concentration lowers the glass reaction affinity [12] and glass reaction rate decreases with time before acceleration. When the solution concentration reaches the solubility limit of a given secondary nhase and the nucleation barrier is overcome, the formation of the secondary phase reduces the solution concentration (activity) and increases the glass reaction affinity, resulting in glass reaction acceleration. Figures $3 a$ to $3 \mathrm{c}$ show the gradual increase in the formation of surface precipitates. At 98 days (Figures 3a), few 
surface precipitates are visible. The amount of surface precipitates increases at 182 days (Figure 3b). The surfaces are fully covered with white precipitates (Figure 3c) at 364 days (note that Figures $3 b$ and $3 c$ are at the same magnifications). The dominant zeolite phase (e.g., clinoptilolite) present in the 330,364, and 390-day samples is not observed for samples up to 182 days, and this zeolite phase may be a main contributor to the acceleration of $200 \mathrm{~S}$ at SAV of $20,000 \mathrm{~m}^{-1}$. However, the origination of these phases in $200 \mathrm{~S}$, not in 200R, may still be a result of the high solution $\mathrm{pH}$ of $200 \mathrm{~S}$.

The reduction in glass reaction affinity results from the decrease in solution concentrations (activities) of the elements that make up the secondary phasies. However, reduction in elemental concentrations is usually difficult to assess directly from the concentration measured. This is because many factors, such as solution $\mathrm{pH}$, ionic strength, and glass dissolution, influence solution activities besides secondary phase formations. Table $\mathrm{I}$ is a list of concentrations of the relevant species for the formation of clinoptilolite (or K-feldspar) before and after acceleration of $200 \mathrm{~S}$ at $20,000 \mathrm{~m}^{-1}$. In general, the boron and alkali concentrations keep increasing with time and have large increases during the acceleration period. The Al concentration decreases more than four times during acceleration. The Si concentration also decreases eventually, reaching a level of $600 \mathrm{mg} / \mathrm{L}$ at 390 days. The reduction in observed concentrations of $\mathrm{Si}$ and $\mathrm{Al}$ correlates with the formation of the zeolite phases and serves as evidence for the reaction affinity control.

\section{CONCLUSIONS}

Static tests at SAN of 340 and $2000 \mathrm{~m}^{-1}$ up to 560 days on three SRL nuclear waste glass compositions show similar reactivity and leach trend between radioactive and simulated nuclear waste glasses with similar chemical compositions. A large difference in reactivity (up to a factor of about 40 in leach rates of boron) has been observed between $200 \mathrm{R}$ and $200 \mathrm{~S}$ glasses when tested at SAV of $20,000 \mathrm{~m}^{-1}$ within one year. The accelerated glass reaction with the simulated glass $200 \mathrm{~S}$ is associated with the formation of crystalline phases such as a clinoptilolite (or K-feldspar), and a pH excursion. The radiation field generated by the fully radioactive glass reduces the solution $\mathrm{pH}$. This lower solution $\mathrm{pH}$, in turn, may relard the onset of increased reaction rate. The radiation field of the radioactive glass has not been found to have any direct effect on the development of the surface alteration layers on glasses. These results suggest that radioactive glass 200R may leach much less than the corresponding simulated glass 2005 under similar test conditions, if the leachate $\mathrm{pH}$ of $200 \mathrm{R}$ can be kept lower than that of $200 \mathrm{~S}$. In

Table 1

Leachate Concentrations (mg/L) $(0.45 \mu \mathrm{m}$ Filtrate) of $200 \mathrm{~S}$ at $20,000 \mathrm{~m}^{-1}$ Before and After Acceleration

\begin{tabular}{|l|c|c|c|c|c|}
\hline \hline Days & $\mathrm{B}$ & $\mathrm{Li}$ & $\mathrm{K}$ & $\mathrm{Al}$ & $\mathrm{Si}$ \\
\hline \hline 98 & $499 \pm 1$ & $107 \pm 5$ & $191 \pm 1$ & $4.7 \pm 0.1$ & $608 \pm 3$ \\
\hline 182 & $642 \pm 14$ & $117 \pm 16$ & $287 \pm 11$ & $3.4 \pm 1.1$ & $833 \pm 12$ \\
\hline 300 & 6389 & 439 & 1783 & 1.1 & 2421 \\
\hline 364 & 22275 & 1071 & 4467 & 0.8 & 1444 \\
\hline 390 & 20924 & 1190 & 4706 & 0.4 & 661 \\
\hline
\end{tabular}

"The values with errors are calculated from the duplicate tests and the remaining values are from s singular test that has an analytical error of less than $10 \%$. 
modeling the performance of glass, all factors, such as the radiation-induced $\mathrm{pH}$ reduction in the leachate discussed above, that influence glass reaction must be accounted for to make adequate long-term predictions. Meaningful comparison tests between radioactive and simulated nuclear waste glasses should include long-term and high SAN tests.

\section{ACKNOWLEDGMENTS}

Work supported by the U.S. Department of Energy, Office of Environmental Restoration and Waste Management, under Contract W-31-109-ENG-38. The authors wish to thank J. E. Battles, N. E. Bibler, and W. Lutze for the review, and to R. Riel for the preparation of this manuscript.

\section{REFERENCES}

1. A. R. Hall, A. Hough and J.A.C. Marples, DOE/RW/89/115; AERE-R-13071 (1988).

2. L. Werme, I. K. Bjorner, G. Bart, H. U. Zwicky, B. Grambow, W. Lutze, R. C. Eving, and C. Magrabi, J. Mater. Res. 5 , 1130(1990); JSS-Project Phase II: Final Report of Work Performed at Studsvik Energiteknic AB and at Swiss Federal Institute for Reactor Research, Japanese, Swiss, Swedish Project Report JSS-85$01(1985)$.

3. J. K. Bates, High Level Radioactive Waste Management, Proc. 2nd Ann. Inter. Conf., 1, 700 (1991).

4. J. A. C. Marples, N. Godon, F. Lanza, and P. Van Iseghem, Radioact. Waste Mgmt. and Disposal, 287 (1991).

5. N. E. Bibler, Adv. Ceram. 20, 619 (1986).

6. X. Feng, and J. K. Bates, Proc. of Third Internat. Conf. on High-Level Radioactive Waste Mgmt., 925-933 (1992); J. K. Bates, X. Feng, C. R. Bradley, and

E. C. Buck, Waste Management '92, 1047-1053 (1992).

7. E. Vernaz, N. Godon, EUR Report \#12017, 15-24 (1989).

8. J.-C. Dran, J.-C. Petit, L. Trotignon, A. Paccagnella, G. Della Mea, Mat. Res. Soc. Symp. Proc. 127, 25-32 (1989).

9. R. C. Surdam, in Mineralogy and Geology of Natural Zeolites, F. A. Mumption, ed., Mineralogical Society of America, 4, 84 (1977); A. J. Gude, 3rd, in ibid, 4, 221 (1977).

10. K. G. Knauss, W. L. Bourcier, K. D. McKeegan, C. I. Merzbacher, S. N. Nguyen, F. J. Ryerson, D. K. Smith, H. D. Weed, and L. Newton, Mat. Res. Soc. Symp. Proc. 176, 371 (1990).

11. X. Feng, I. L. Pegg, Q. Yan, X. Mao and P. B. Macedo, Nucl. Waste Manag. IV, Ceramic Trans. 23, 95-104 (1991).

12. W. L. Bourcier, D. W. Peiffer, K. G. Knauss, K. D. McKeegan, and D. K. Smith, Mat. Res. Soc. Symp. Proc. 176, 209-216 (1990).

\section{DISCLAIMER}

This report was prepared as an account of work sponsored by an agency of the United States Government. Neither the United States Government nor any agency thereof, nor any of their employees, makes any warranty, express or implied, or assumes any legal liability or responsibility for the accuracy, completeness, or usefulness of any information, apparatus, product, or brocess disclosed, or represents that its use would not infringe privately owned rights. Reference herein to any specific commercial product, process, or service by trade name, trademark, manufacturer, or otherwise does not necessarily constitute or imply its endorsement, recommendation, or favoring by the United States Government or any agency thereof. The views and opinions of authors expressed herein do not necessarily state or reflect those of the United States Government or any agency thereof. 


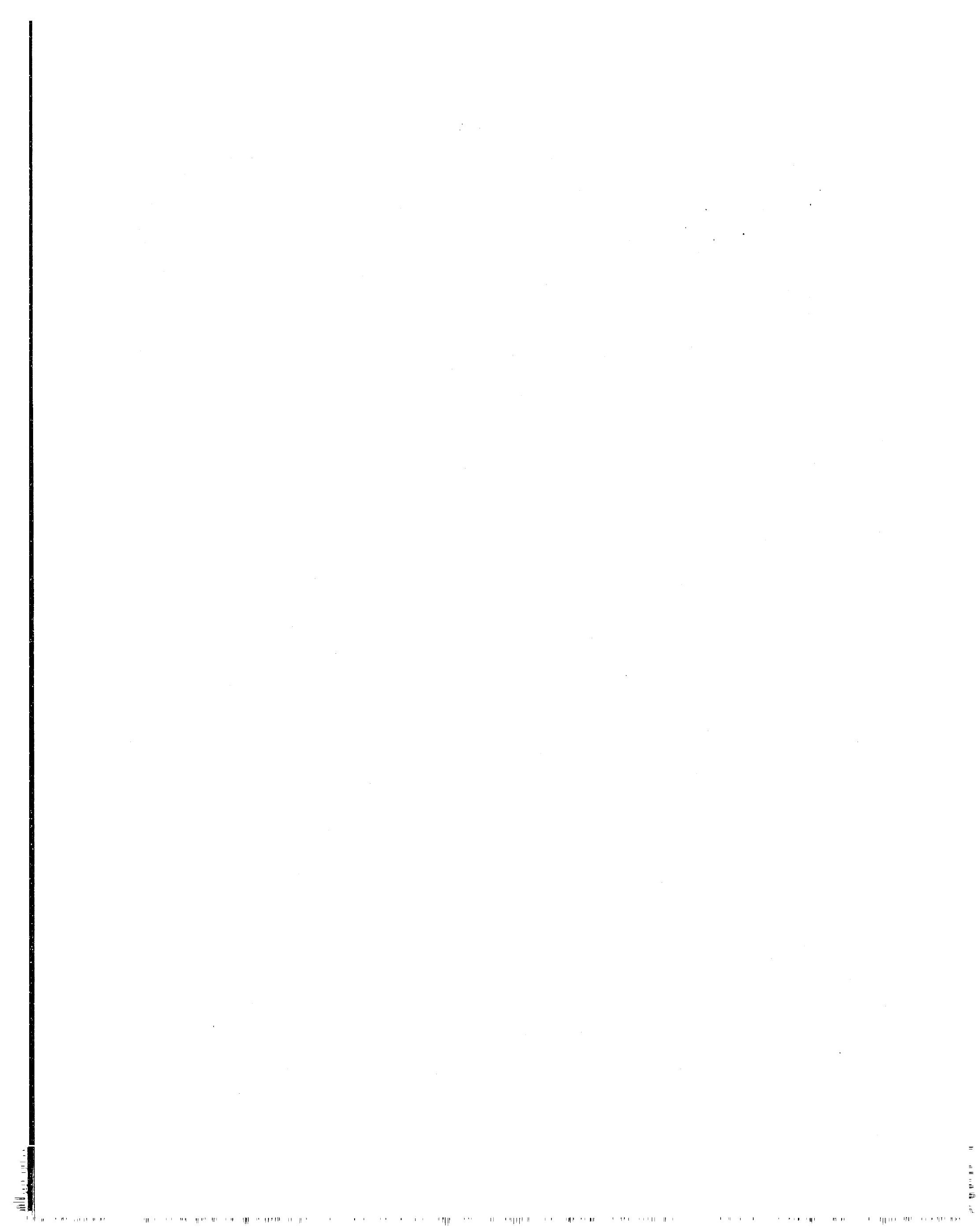

